\title{
A Hybrid Virtual Cloud Learning Model during the COVID-19 Pandemic
}

\author{
Shaymaa E. Sorour ${ }^{1, *}$, Tamer M. Kamel ${ }^{2}$ and Hanan E. Abdelkader ${ }^{3}$ \\ ${ }^{1}$ Department of Educaion Technology (Computer Teacher Preparation), Kafrelsheikh University, 33516, Egypt \\ ${ }^{2}$ Department of Educaion Technology, Kafrelsheikh University, 33516, Egypt \\ ${ }^{3}$ Department of Computer Teacher Preparation, Mansoura University, 35516, Egypt \\ ${ }^{*}$ Corresponding Author: Shaymaa E. Sorour. Email: Shaymaa.srour@spe.kfs.edu.eg \\ Received: 18 September 2020; Accepted: 22 October 2020
}

\begin{abstract}
The COVID-19 pandemic has affected the educational systems worldwide, leading to the near-total closures of schools, universities, and colleges. Universities need to adapt to changes to face this crisis without negatively affecting students' performance. Accordingly, the purpose of this study is to identify and help solve to critical challenges and factors that influence the e-learning system for Computer Maintenance courses during the COVID-19 pandemic. The paper examines the effect of a hybrid modeling approach that uses Cloud Computing Services (CCS) and Virtual Reality (VR) in a Virtual Cloud Learning Environment (VCLE) system. The VCLE system provides students with various utilities and educational services such as presentation slides/text, data sharing, assignments, quizzes/tests, and chatrooms. In addition, learning through VR enables the students to simulate physical presence, and they respond well to VR environments that are closer to reality as they feel that they are an integral part of the environment. Also, the research presents a rubric assessment that the students can use to reflect on the skills they used during the course. The research findings offer useful suggestions for enabling students to become acquainted with the proposed system's usage, especially during the COVID-19 pandemic, and for improving student achievement more than the traditional methods of learning.
\end{abstract}

Keywords: Virtual cloud learning environment; virtual reality environment; rubric assessment; COVID-19; critical challenges

\section{Introduction}

The global pandemic of COVID-19 has led to calls for social distancing. Among the regulations instituted to fight the virus, citizens have been told to remain indoors, where they are often idle, leading often to mental stress. Staying mentally engaged is one way to reduce mental stress, and as such online learning can play an important role in such an engagement. Indeed, online learning is considered to be the best solution to engagement during the pandemic. Teachers can use virtual classrooms to teach from home with tools that make online sessions effective and efficient. Pandemics often compel learners to stay at home for long periods of time and obstruct

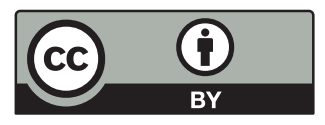

This work is licensed under a Creative Commons Attribution 4.0 International License, which permits unrestricted use, distribution, and reproduction in any medium, provided the original work is properly cited. 
the teaching-learning process [1,2]. Therefore, to face the COVID-19 pandemic, educational institutions must adopt the best methods of providing inexpensive and highly efficient services using academic tools and research practices. The UNESCO [3] lists educational applications, platforms, and resources as distance learning solutions that aim to help parents, teachers, schools, and school administrators facilitate the student-learning process and provide social care and interaction during periods of school closure. Most of the solutions devised are free and many cater to multiple languages. They tend to have a wide reach, a strong user-base, and evidence of impact. They are categorized based on distance learning needs, while most of them offer functionalities across multiple categories. One item on the list is Digital Learning Management Systems, which contain Moodle as a community-driven and globally supported open learning platform, as an essential cloud computing tool.

Cloud Computing Services (CCS) have received notable attention in various information technology fields. They utilize many services as structured storage systems as well as social networking and distributed file systems to ease data sharing, storage, multi-format content, and synchronization [4,5]. For this reason, many educational institutions have adopted CCS technology, which makes it easy for users to reinforce their educational expertise via services that can be accessed anywhere and anytime without having to worry about working cloud services or their location [6-8].

According to the existing research, using CCS has several benefits. Firstly, CCS supply e-learning services like simulations, virtual worlds, and video streaming in Massive Open Online Courses. They supply teachers and students with useful methods from computing resources for laboratories and lectures based on specific learning needs. Teachers can design and implement virtual computers (also called Virtual Machines or VMs) with pre-installed software to deploy computing laboratories quickly [9-11]. Secondly, cloud computing is cost-effective and therefore useful when resources are unavailable or scarce, and academics gain a positive and valuable experience from using it. Thirdly, CCS technology can support students and academics. Fourthly, it allows users to share, edit, process, and save massive amounts of data in educational environments and to use teaching and learning [12,13]. Lastly, CCS create a personalized learning environment or virtual learning and teaching communities [14,15].

In this research, a hybrid modeling approach with CCS and VR was applied in a Virtual Cloud Learning Environment (VCLE) system. This approach and VCLE system were intended to overcome problems that students may face in learning during computer maintenance courses and to avoid obstacles caused by the students' physical absence from university during the COVID-19 pandemic. Under the circumstances, the students may struggle to identify errors in their learning or practice efficiently, and they may lack many services that can help them learn using traditional methods. The proposed system helps teachers to recognize problems, such as when students make mistakes, by analyzing student submissions. It also permits the teachers to enhance teaching sources and tools [16].

The VR environment is a collection of the educational methods, intended to improve students achievement by making computers and Internet as an essential part of the educational process, such as by providing web-based access to classrooms, grades, and reports [17]. Thus, VR systems facilitate many educational procedures for both students and teachers in the following areas: management, connection, participation, administration, and syllabus preparation [18]. The main goal of using these environments in this research is to provide students with valuable data as well as interaction with the subject, and to generate an optimal model of learner's activities [19-21]. 
In this situation, learners feel connected to the environmental components [22]. In this research, VR was applied with CCS to explore student-learning outcomes. The proposed system enables both teachers and students to share information and introduce teaching opportunities that can enhance productivity, improve ease and support traditional teaching-learning methods. The system aims to improve students' ability to learn more profoundly. There are specific student characteristics that can be associated with students' success rate and performance improvement. Our goal is to help students to perform well and provide all the necessary educational services through the VCLE system. Also, the feedback process was added to help improve students' learning process during the course [23]. Furthermore, many CCS and tools were employed in the VCLE to offer innovative opportunities for education. Rubric assessments were used to estimate students' performance and skills in the educational environment. Rubrics are highly regarded as tools that increase validity and accuracy in assessment [24] because they provide clear evaluation criteria, data quality, and scoring plans [8]. In this research, we also used evaluation criteria as a kind of rubric evaluation to estimate students' skill performance in computer maintenance to increase the validity and accuracy of achieving the practical goals.

To improve student performance and develop a practical implementation, this study examines the use of the VCLE system with a rubric assessment, applied with the following objectives: (i) To increase student satisfaction with learning environment, (ii) To use Virtual Reality (VR) videos to encourage students to learn more deeply, and (iii) To improve student performance by eliciting feedback in consecutive lectures and tracking students' learning situation.

The rest of the paper is organized as follows. Section 2 provides an overview of the related work. Section 3 explains the proposed VCLE system with a rubric assessment. Section 4 introduces the rubric assessment for the Computer Maintenance course. Section 5 discusses the main experimental results. Finally, Section 6 concludes the paper.

\section{Literature Review}

\subsection{Virtual Reality and Cloud Computing in Learning}

E-learning employs a variety of virtual learning tools, and cloud computing is often discussed as a way to provide assistance to e-learning frameworks. Fig. 1 shows the cloud computing structure for e-learning applications and provides some examples of e-learning approaches to the cloud computing applications [25]. E-learning in the cloud is considered to be an educational program and a service. Content can be published very quickly, and there are a few hardware requirements for users. Moreover, it reduces the burden of maintenance and support on the educational institution and allows users to receive the latest system updates without paying extra fees and to share main resources [26]. E-learning systems are currently being developed at a fast rate. Accordingly, some challenges that arise include optimizing resource calculation, storage communication requirements, and handling requests for dynamic synchronization.

Hence, the importance of cloud computing as a platform meets scalable and cost control requirements. Various scientific contributions address the importance of employing CCS in education. For instance, Liao et al. [27] described that cloud services have already been approved in the educational sector, where various educational institutions in the United States have emphasized the ability of cloud computing to improve efficiency, cut costs, and facilitate learning in addition to research. Derboven et al. [28] showed improvements in students' collaboration and learning experiences when they used education-based cloud services like the Google App Education, which includes Google, email and document sharing, and provides benefits similar to those of its rivals 
(e.g., Microsoft). Derboven et al. [28] described the virtual learning environments used by many higher educational institutions. A detailed explanation was provided on how teachers adapted to the learning environment to meet their needs, using a mixture of semiotic, multimodal analysis and an in-depth study of users with 24 participants.

\subsection{Effect of Rubric Use on Student Performance}

Barney et al. [29] indicated that student outcomes were affected by both rubrics and oral feedback. Their experiment, conducted in the software engineering course, led to statistically significant results. The use of rubrics was found to decrease the number of student complaints and questions related to grades. A rubric was designed to enhance students' understanding and awareness of the nature of multimedia presentation slides [30]. When compared against a control group, students who used the rubric achieved a higher score, and their multimedia illiteracy was reduced. In the study, undertaken [31] students acknowledged using a rubric as a "recipe" that guided them through standard criteria. Students in the control and experimental group assessed their own self-organization, which was considered in terms of its effect on their academic performance. The results indicated that students, who used the rubric performed better compared to those who did not use it. They had greater accuracy in self-evaluation, higher performance scores, and higher scores for self-regulation, as it appears that the rubric aided their self-evaluation [32]. Other factors also contributed to the rubric's utility.Another study used four sources to collect information about the use of rubrics in higher education: Interviews, observations, questionnaires, and documentary analyses. Three case studies from different disciplines were presented, each indicating the importance of students using a rubric to increase their progress and improve their learning efficiency. The students found that the criteria used in the rubric were understandable and useful [33].

In summary, the following statements can be made:

- Several studies have emphasized the importance of both VR and CCS in various educational fields. The incorporation of this technology can improve learners' competence and increase their academic level.

- Free services provided by the cloud can be used to create an active learning environment that is interesting for students and meets their needs, which in turn helps to reduce the cost of the infrastructure.

- Previous studies reviewed the challenges and opportunities that can be focused to use VR technology and CCS in a way that fosters student creativity.

- Rubrics are useful assessment tools that help decrease the number of student complaints and questions related to grades and increase students' skills, particularly in practical fields.

\section{Proposed Framework}

This study designed and utilized the cloud as a SaaS service model [34,35] to combine new services and create a new VCLE system to increase user satisfaction and improve the studentlearning environment in a Computer Maintenance course. The study also adopted Moodle, which is one of the most popular and applied VCLE systems in the educational institutions.

UNESCO [3] has listed some educational applications, platforms, and resources as distance learning solutions that aim to help parents, teachers, schools, and school administrators, facilitate student-learning and provide social care and interaction during the periods of school closure. Fig. 1 presents the proposed system, where the system administrator can upload learning tools such as lecture slides, VR, assignments, quizzes, audio, and video. Each lecturer can allocate 
tasks and items based on the nature of the materials and students' needs. Only students who are enrolled in the module can access the materials and activities. They can submit assignments, send or receive chats, participate in workshops, and contribute to the wiki. The system allows lecturers to organize and manage a virtual class, and provides students with feedback. Most Moodle courses have an IT specialist or system administrator, who has downloaded the open-source code, installed and set it up on a server, and managed all the services in the system.

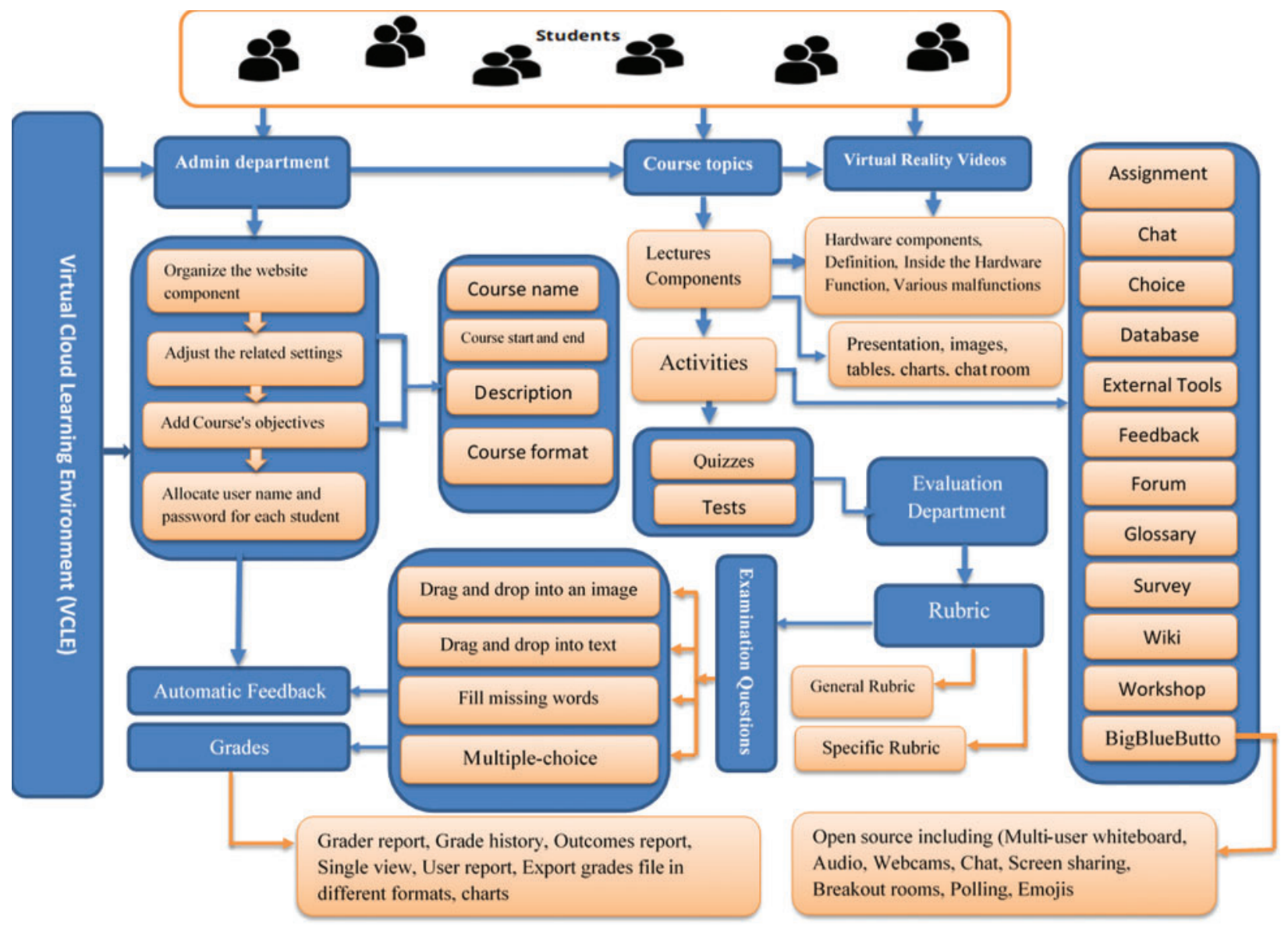

Figure 1: Proposed system framework with critical challenges and factors for use in online learning during the COVID-19 pandemic

The proposed system is designed to serve educational institutions by combining helpful services to make users interested in finishing their tasks appropriately and efficiently. Accordingly, this study provides many VR videos to teach students more deeply detailed knowledge of computer hardware and components. The contents show students how to fix malfunctions, which cannot be seen or dealt with in the traditional learning method.

\subsection{Participants}

The sample consisted of 100 students in the Department of Educational TechnologyComputer Teacher Preparation at Kafrelsheikh University. The students were enrolled in a Computer Maintenance course. They were divided into two groups of 50 students each: Group 1 
studied using the VCLE system, and Group 2 learned with the traditional method (presentation slides accompanied by the lecturer's audio comments). The main subject from Lessons 1-8 was computer hardware; the students learned about the malfunctions of different hardware components (e.g., power supply, hard disk, motherboard, DVD, processor, RAM, Cards) and how to fix bugs. There is often great difficulty in learning using the traditional method, as it is difficult for students to practice and detect problems. Next, from Lessons 9-15, the students learned about computer software, including Windows setup, hard disk partition, Hiren's boot, and antivirus programs. However, our system is concerned with Lessons 1-8.

\subsection{Proposed System Architecture}

\subsubsection{Proposed System Contents}

The proposed system contains of the following components:

- Users: The users are students using the VCLE system and lecturers, who are responsible for developing, organizing, and controlling learning materials, exercises, and other contents.

- VCLE: The VCLE is a new Moodle system that provides variety in terms of the location of services and the way that students can access the service. It also allows users to observe activities, and select and arrange data.

\subsubsection{VCLE System Structure}

(a) The first step was to create a website for the Computers Maintenance course and adjust all the related settings such as the course full and short name, course start and course end, description, appearance, and course format.

(b) The objectives for the course and sub-objectives for each lecture were added to the system. Every student had a username and a password to access the system and navigate all the components. Course topics were divided into lectures, virtual videos, single activities, quizzes, tests, and a standard format.

(c) Every lecture contained the following:

- Lecture contents (text, presentations, virtual videos, images, tables, and charts)

- VR videos with 3D Max that illustrated the subject and enabled students to imagine what might happen in a real-life situation. Fig. 2 displays some snapshots of the VR videos. Fig. 3 presents the VCLE system. Also, each lecture was divided into several videos to teach the internal structure of each component, including how it works and its various faults. Also discussed was how to identify subtle errors and fix the malfunction.

(d) A variety of questions, such as multiple-choice, fill in the missing words, drag and drop into text, drag and drop into an image, true or false, and other types. These trained the students with automatic feedback after each lecture.

(e) Chat rooms available at a specified time. Students could discuss issues related to the lessons or the system with their lecturer. Other activities available in the system were assignments, workshops, and a wiki.

(f) Quizzes. The students could train on several quizzes after each lecture, and the system supported them with adequate automatic feedback.

(g) Information on student's last access to the course, current status, and grades. The system could report for each student individually or all students.

Tests and grades. After finishing the learning process for each objective, students could take the test and receive their final score. All grades were saved in the system, and the lecturer could save and review all students' answers to follow their progress. 

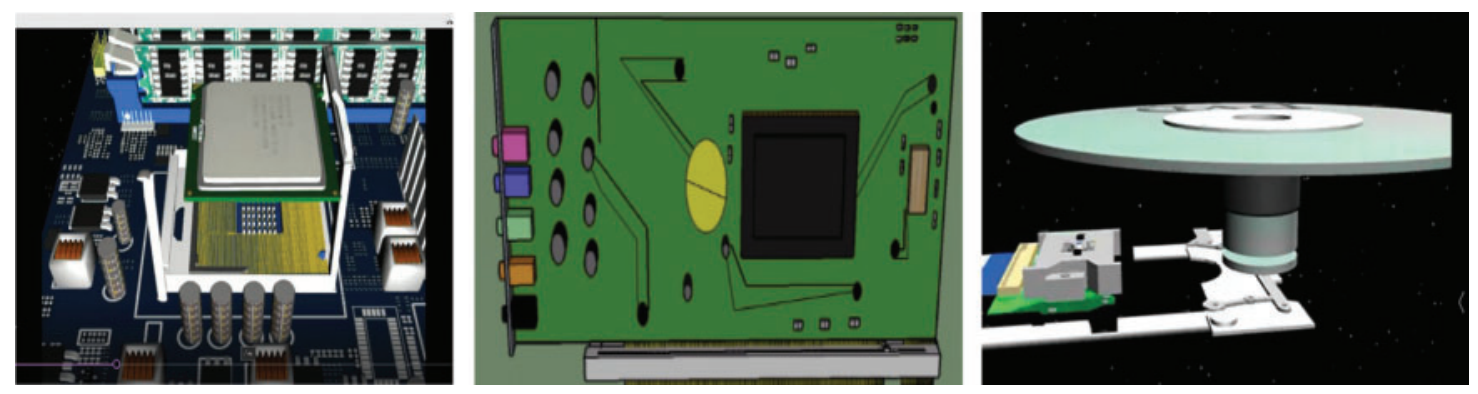

Figure 2: Snapshots of VR used in the computer maintenance course during the COVID-19 pandemic

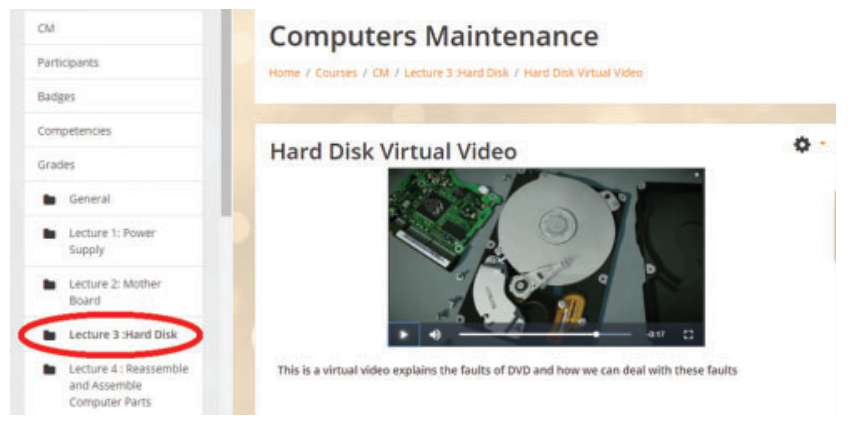

Figure 3: Interface of the VCLE system

\subsubsection{Rubric Assessment for the Computer Maintenance Course}

Rubrics are documents that indicate the expectations for a specific task or set of tasks, via listing the criteria of assessment. They can be used to estimate multidimensional performances [36-38].

In this research, two types of rubric criteria were used to estimate students' skill performance in the Computer Maintenance course. According to the instructions of the Ministry of Higher Education, students shall take their final exams on-site at their university. Students shall come to the university twice before the practical test to be observed in all practical lessons, according to the announced decisions. Tab. 1 shows the first type, "General Rubric for the Computer Maintenance Course." Tab. 2 presents the second type, "A Specific Rubric for Disassembly and Reassembly of the System Unit."

\subsubsection{Rubric Assessment Validity and Reliability}

After we had prepared the General Rubric (7 criteria), and the Specific Rubric (5 criteria) for the Computer Maintenance course, we measured their validity. The validity is an evaluation of how well the rubric measures what it is designed to measure [39,40]. This study used referee validity to measure the validity of rubrics. The rubrics were given to specialists in computer science, curricula, and teaching methods to ensure that the criteria were suitable to the specific goals of the study. Fig. 4a shows the opinions of the specialists, who were given the General Rubric specialists; Fig. 4b shows the opinions of those who received the Specific Rubric. 
Table 1: General rubric for the computer maintenance course

\begin{tabular}{|c|c|c|c|c|}
\hline Criterion & $\begin{array}{l}\text { Excellent } \\
9-10\end{array}$ & Good 7-8 & Poor 4-6 & Unacceptable $0-3$ \\
\hline $\begin{array}{l}\text { Familiarity } \\
\text { (identification of } \\
\text { different } \\
\text { hardware) }\end{array}$ & $\begin{array}{l}\text { In-depth coverage of the } \\
\text { topic; Topic is } \\
\text { appropriate for the } \\
\text { assignment; Strong } \\
\text { basis in sound, } \\
\text { research-based } \\
\text { information; } \\
\text { Outstanding clarity; } \\
\text { Hyperlinks to credible } \\
\text { sites }\end{array}$ & $\begin{array}{l}\text { Good coverage of the } \\
\text { topic; Topic is } \\
\text { appropriate to the } \\
\text { assignment; Basis in } \\
\text { sound, research-based } \\
\text { information; Clear and } \\
\text { understandable; } \\
\text { Hyperlinks to credible } \\
\text { sites }\end{array}$ & $\begin{array}{l}\text { Topic inadequately } \\
\text { covered; Topic is } \\
\text { appropriate to the } \\
\text { assignment, not based } \\
\text { on research-based } \\
\text { information; Clear and } \\
\text { understandable; } \\
\text { Hyperlinks to } \\
\text { non-credible sites }\end{array}$ & $\begin{array}{l}\text { Coverage of the topic; } \\
\text { Topic is inappropriate } \\
\text { for the assignment, not } \\
\text { based on } \\
\text { research-based } \\
\text { information; Unclear } \\
\text { and confusing; No } \\
\text { hyperlinks }\end{array}$ \\
\hline $\begin{array}{l}\text { Detailing function } \\
\text { of computer part }\end{array}$ & $\begin{array}{l}\text { All computer parts } \\
\text { described correctly }\end{array}$ & $\begin{array}{l}\text { There are } 1-2 \text { mistakes } \\
\text { in describing computer } \\
\text { parts }\end{array}$ & $\begin{array}{l}\text { There are } 3-4 \text { mistakes } \\
\text { in describing computer } \\
\text { parts }\end{array}$ & $\begin{array}{l}\text { There are } 5 \text { or more } \\
\text { mistakes in describing } \\
\text { computer parts }\end{array}$ \\
\hline Safety & $\begin{array}{l}\text { Utilizing the secure } \\
\text { handling of all tools } \\
\text { during practical } \\
\text { applications in the } \\
\text { maintenance } \\
\text { laboratory }\end{array}$ & $\begin{array}{l}\text { Not utilizing the secure } \\
\text { handling of all tools } \\
\text { once during practical } \\
\text { applications in the } \\
\text { maintenance } \\
\text { laboratory }\end{array}$ & $\begin{array}{l}\text { Not using the secure } \\
\text { handling of all tools } \\
\text { twice during practical } \\
\text { applications in the } \\
\text { maintenance } \\
\text { laboratory }\end{array}$ & $\begin{array}{l}\text { Not using the secure } \\
\text { handling of all tools } \\
\text { three times or more } \\
\text { during practical } \\
\text { applications in the } \\
\text { maintenance } \\
\text { laboratory }\end{array}$ \\
\hline Accuracy & $\begin{array}{l}\text { Each voltage of wires is } \\
\text { measured correctly }\end{array}$ & $\begin{array}{l}\text { There are } 1-2 \text { mistakes } \\
\text { in measur- } \\
\text { ing/determining the } \\
\text { voltage of wires }\end{array}$ & $\begin{array}{l}\text { There are } 3-4 \text { mistakes } \\
\text { in measur- } \\
\text { ing/determining the } \\
\text { voltage of wires }\end{array}$ & $\begin{array}{l}\text { There are } 5 \text { or more } \\
\text { mistakes in measur- } \\
\text { ing/determining the } \\
\text { voltage of wires }\end{array}$ \\
\hline $\begin{array}{l}\text { Identifying } \\
\text { malfunctions and } \\
\text { solving them }\end{array}$ & $\begin{array}{l}\text { Identifying all } \\
\text { malfunctions and } \\
\text { solving them }\end{array}$ & $\begin{array}{l}\text { There are } 1-2 \text { mistakes } \\
\text { in identifying } \\
\text { malfunctions and } \\
\text { solving them }\end{array}$ & $\begin{array}{l}\text { There are } 3-4 \text { mistakes } \\
\text { to in identifying } \\
\text { malfunctions and } \\
\text { solving them }\end{array}$ & $\begin{array}{l}\text { There are } 5 \text { or more } \\
\text { mistakes in identifying } \\
\text { malfunctions and } \\
\text { solving them }\end{array}$ \\
\hline $\begin{array}{l}\text { Organization } \\
\text { (presenter and } \\
\text { oral presentation) }\end{array}$ & $\begin{array}{l}\text { Presenter and oral } \\
\text { presentation are } \\
\text { well-organized; He/she } \\
\text { discusses the content, } \\
\text { seldom referring to } \\
\text { notes during the } \\
\text { presentation }\end{array}$ & $\begin{array}{l}\text { Presenter and oral } \\
\text { presentation are } \\
\text { organized; He/she } \\
\text { explains the content, } \\
\text { occasionally referring } \\
\text { to notes during the } \\
\text { presentation }\end{array}$ & $\begin{array}{l}\text { Presenter and oral } \\
\text { presentation are } \\
\text { poorly organized; } \\
\text { He/she frequently } \\
\text { relies on notes during } \\
\text { the presentation }\end{array}$ & $\begin{array}{l}\text { Presenter and oral } \\
\text { presentation are } \\
\text { well-organized; He/she } \\
\text { reads the slides and or } \\
\text { notes during the } \\
\text { presentation }\end{array}$ \\
\hline $\begin{array}{l}\text { Appearance } \\
\text { (presenter) }\end{array}$ & $\begin{array}{l}\text { Engages the audience } \\
\text { well; Displays } \\
\text { professional } \\
\text { appearance; Uses } \\
\text { volume and elocution } \\
\text { appropriate to the } \\
\text { setting; Maintains } \\
\text { excellent eye contact, } \\
\text { posture, and } \\
\text { composure }\end{array}$ & $\begin{array}{l}\text { Engages the audience; } \\
\text { Displays professional } \\
\text { appearance; Uses } \\
\text { volume and elocution } \\
\text { appropriate to the } \\
\text { setting; Maintains } \\
\text { good eye contact, } \\
\text { attitude, and } \\
\text { composure }\end{array}$ & $\begin{array}{l}\text { Engages the audience } \\
\text { poorly; Presents a } \\
\text { poor professional } \\
\text { appearance; Uses } \\
\text { volume and elocution } \\
\text { inappropriate to the } \\
\text { setting; Maintains } \\
\text { minimal eye contact, } \\
\text { posture, and } \\
\text { composure }\end{array}$ & $\begin{array}{l}\text { Presenter does not } \\
\text { engage the audience; } \\
\text { Displays } \\
\text { unprofessional } \\
\text { appearance; Is } \\
\text { inaudible; Does not } \\
\text { maintain eye contact; } \\
\text { Displays poor posture } \\
\text { and lack of composure }\end{array}$ \\
\hline
\end{tabular}


Table 2: Specific rubric in disassembly and reassembly of the system unit

\begin{tabular}{|c|c|c|c|c|}
\hline$\overline{\text { Criterion }}$ & $\begin{array}{l}\text { Excellent } \\
9-10\end{array}$ & $\begin{array}{l}\text { Good } \\
7-8\end{array}$ & $\begin{array}{l}\text { Poor } \\
4-6\end{array}$ & $\begin{array}{l}\text { Unacceptable } \\
0-3\end{array}$ \\
\hline Accuracy & $\begin{array}{l}\text { All the cables } \\
\text { (data, power) and } \\
\text { components are } \\
\text { placed and fixed } \\
\text { properly }\end{array}$ & $\begin{array}{l}\text { There are } 1-2 \\
\text { cables or parts } \\
\text { not placed and } \\
\text { fixed properly }\end{array}$ & $\begin{array}{l}\text { There are } 3-4 \\
\text { cables or } \\
\text { components not } \\
\text { placed and fixed } \\
\text { properly }\end{array}$ & $\begin{array}{l}\text { There are } 5 \text { or } \\
\text { more cables or } \\
\text { components not } \\
\text { placed and fixed } \\
\text { properly }\end{array}$ \\
\hline Familiarity & $\begin{array}{l}\text { All the questions } \\
\text { are answered } \\
\text { correctly }\end{array}$ & $\begin{array}{l}\text { There are } 1-2 \\
\text { questions not } \\
\text { answered correctly }\end{array}$ & $\begin{array}{l}\text { There are } 3-4 \\
\text { questions not } \\
\text { answered correctly }\end{array}$ & $\begin{array}{l}\text { There are } 5 \text { or } \\
\text { more questions } \\
\text { not answered } \\
\text { correctly }\end{array}$ \\
\hline Functionality & $\begin{array}{l}\text { The computer is } \\
\text { working correctly } \\
\text { in the } 1 \text { st } \\
\text { reassembly test }\end{array}$ & $\begin{array}{l}\text { The computer is } \\
\text { working correctly } \\
\text { in the } 2 \text { nd } \\
\text { reassembly test }\end{array}$ & $\begin{array}{l}\text { The computer is } \\
\text { working correctly } \\
\text { in the } 3 \text { rd } \\
\text { reassembly test }\end{array}$ & $\begin{array}{l}\text { The computer is } \\
\text { working correctly } \\
\text { in the } 4 \text { th or } \\
\text { further attempt } \\
\text { of the reassembly } \\
\text { test }\end{array}$ \\
\hline Senses & $\begin{array}{l}\text { Utilized all } 5 \\
\text { guidelines safely } \\
\text { during } \\
\text { disassembly and } \\
\text { reassembly }\end{array}$ & $\begin{array}{l}\text { Utilized only } 3-5 \\
\text { guidelines safely } \\
\text { during } \\
\text { disassembly and } \\
\text { reassembly }\end{array}$ & $\begin{array}{l}\text { Utilized only 1-2 } \\
\text { guidelines safely } \\
\text { during } \\
\text { disassembly and } \\
\text { reassembly }\end{array}$ & $\begin{array}{l}\text { Did not utilize } \\
\text { guidelines safely } \\
\text { during } \\
\text { disassembly and } \\
\text { reassembly at all }\end{array}$ \\
\hline Timeliness & $\begin{array}{l}\text { Finished } \\
\text { disassembly and } \\
\text { reassembly of the } \\
\text { system unit } \\
\text { within } 20 \mathrm{~min}\end{array}$ & $\begin{array}{l}\text { Finished } \\
\text { disassembly and } \\
\text { reassembly of the } \\
\text { system unit } \\
\text { within } 35 \mathrm{~min}\end{array}$ & $\begin{array}{l}\text { Finished } \\
\text { disassembly and } \\
\text { reassembly of the } \\
\text { system unit } \\
\text { within } 45 \text { min }\end{array}$ & $\begin{array}{l}\text { Finished } \\
\text { disassembly and } \\
\text { reassembly of the } \\
\text { system unit in } 1 \mathrm{~h}\end{array}$ \\
\hline
\end{tabular}

\subsubsection{VCLE System Mechanism}

- Before the lecture time, the system sends emails to all students as notifications about the lecture topic and schedule.

- Each student is logging in the VCLE system using his username and password.

- The system is opened, and students can meet his colleagues and teacher in the chatroom.

- The lecturer can download his lecture and explain the overall objective and sub-objectives. Also, the lecturer allow students to watch all the required videos, activities, audio, reading content, to communicate with students and excitingly connect the subject.

- Students can use raise hand tool if they have a question, and the lecturer answers their question.

- Before the lecture ends, the lecturer proposes a summary of the course then asks some questions to students.

- Students can sign in to online-specific assignments such as responding to lecturer-posed questions in a discussion board, or answer the quiz after the lecture. 
- VCLE system provides dashboards for the lecturer to easily help them supervise their students online, furthermore predicts at-risk students who might fail to pass their final exams.

- The use of rubric assessments might help predict students with lower performance and who can be at risk of failing to pass their final exams; and, provides real-time interventions, like notifications, by providing supportive learning content for students while learning.

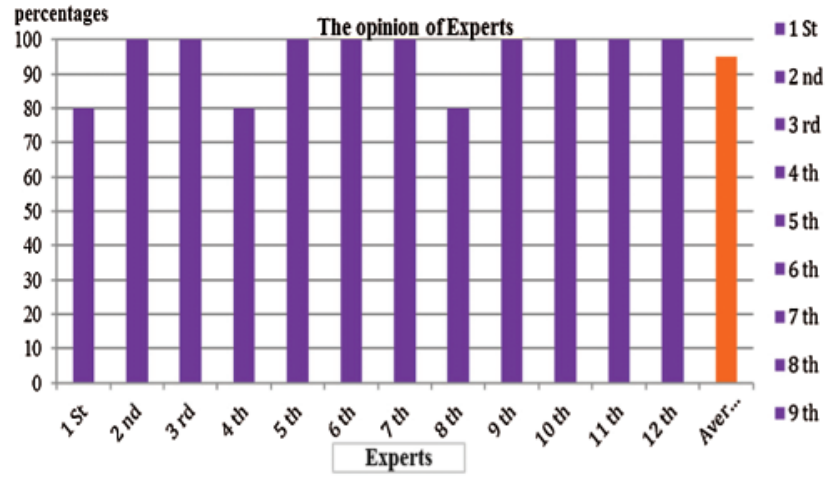

(a)

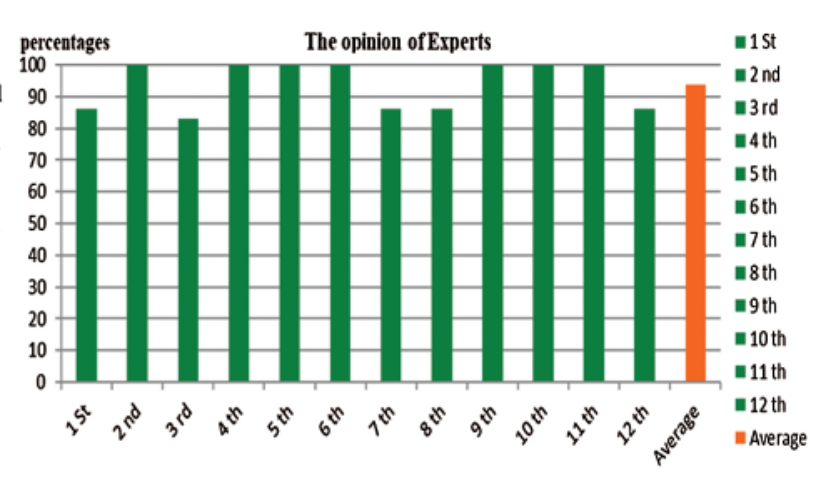

(b)

Figure 4: (a) Specialists' opinions on the general rubric (b) specialists' opinions on the specific rubric

\section{Results}

This section is divided into three subsections. The first compares the VCLE group with the traditional group, the second illustrates the effect of lecture quizzes, and the third describes the rubric assessment. First, we checked the homogeneity of variances for the data, Levene Statistic = 0.488. A descriptive quantitative analysis was performed using SPSS 23.00.

\subsection{VCLE System}

The difference in the pre-test scores between the two groups was not significant, while the t-test between the two groups in the post-test $(t=13.029, p<.01)$ was significant. Meanwhile, the difference between the pre- and post-test scores was significant for the experimental group $(t=-3.029, p<.01)$ as well as the traditional group $(t=-48.821, p>.05)$. This means the VCLE activities were helpful to stimulate student-learning achievement.

A pair sample t-test was used to analyze the pre- and post-test scores for each group, as shown in Tabs. 3 and 4. The mean difference was 9.50. The correlation of the pre-test was $0.67, p<.01$, and there was no significant enhancement in the pre-test, where $t=1.159$. The mean, $\mathrm{SD}$, and SEM were $0.16000,0.97646$, and 0.13809 , respectively. In the post-test, the correlation was $-.068, p>.05, t=13.029$. The mean, SD, and SEM were 9.50000, 5.15574, and 0.72913, respectively, and is a significant enhancement in the post-test for the VCLE group where $p<.01$.

Tab. 5 shows the means and SDs of the post-test for the two groups using an independent samples test. Students in the VCLE group gained significantly higher scores on the post-test (F 102.2, $p<.01$ ). They demonstrated better levels of improvement in the Computer Maintenance course than their counterparts in the traditional group. 
Table 3: Descriptive statistics for the traditional and experimental groups: pre- and post-test scores

\begin{tabular}{|c|c|c|c|c|c|c|c|}
\hline \multirow[t]{2}{*}{ Group } & \multirow[t]{2}{*}{$\mathrm{N}$} & \multicolumn{2}{|c|}{ Pre-test } & \multicolumn{2}{|c|}{ Post-test } & \multirow[t]{2}{*}{$\mathrm{t}$} & \multirow[t]{2}{*}{$\mathrm{P}$} \\
\hline & & $\mathrm{M}$ & SD & $\bar{M}$ & SD & & \\
\hline$T$ & 50 & 4.12 & 1.11 & 40.00 & 5.026 & -48.821 & $>.05$ \\
\hline$V L C E$ & 50 & \multicolumn{2}{|c|}{$t=1.159$} & $\begin{array}{l}49.50 \\
t=13\end{array}$ & $9^{1.233}$ & $13.029-$ & .000 \\
\hline
\end{tabular}

Table 4: T-test results for the VCLE and traditional groups

\begin{tabular}{lllllllllll}
\hline & N & M & SD & SEM & $\begin{array}{l}95 \% \text { Confidence interval } \\
\text { of the difference }\end{array}$ & & T & df & $\mathrm{p}$ \\
& & & & & & & \\
& & & & Lower & Upper & & \\
\hline Pre-post groups & 50 & -9.50 & 5.16 & 0.731 & -10.97 & -8.035 & & -13.03 & 49 & .000 \\
\hline
\end{tabular}

Table 5: T-test results for the post-test scores of the VCLE and traditional groups

\begin{tabular}{lllllll}
\hline Group & $\mathrm{N}$ & $\mathrm{M}$ & $\mathrm{SD}$ & SEM & $\mathrm{T}$ & $\mathrm{P}$ \\
\hline$T$ & 50 & 40.0 & 5.02 & 0.711 & 12.979 & .00 \\
$V C L E$ & 50 & 49.0 & 1.23 & 174.0 & & \\
\hline
\end{tabular}

\subsection{Cloud-Based VCLE System Using Lecture Quizzes}

Tab. 6 shows the one-way ANOVA results for the two groups using lecture quizzes (4 tests). The VCLE group achieved the most positive and high mean scores on all quizzes. Figs. 5 and 6 show students' grades on all the lecture quizzes for the two groups, and Fig. 7 presents the overall quiz average between the two groups.

Table 6: ANOVA results using lectures quizzes

\begin{tabular}{lllllll}
\hline Subject & & $\mathrm{M}$ & SD & SEM & F & Sig. \\
\hline Test 1 & $V C L E$ & 11.24 & 1.31 & 0.184 & 202.707 & .000 \\
& $T$ & 7.64 & 1.22 & 0.173 & & \\
Test 2 & $V C L E$ & 11.95 & 1.40 & 0.198 & 92.382 & .000 \\
& $T$ & 9.37 & 1.28 & .181 & & \\
Test 3 & $V C L E$ & 7.64 & 1.19 & 0.168 & 289.661 & .000 \\
& $T$ & 4.12 & 0.849 & .120 & & \\
Test 4 & VCLE & 13.52 & 1.79 & .253 & 282.185 & .000 \\
& $T$ & 7.96 & 1.51 & 0.214 & & \\
\hline
\end{tabular}


VCLE Group: Students Degrees with Lectures Quizzes

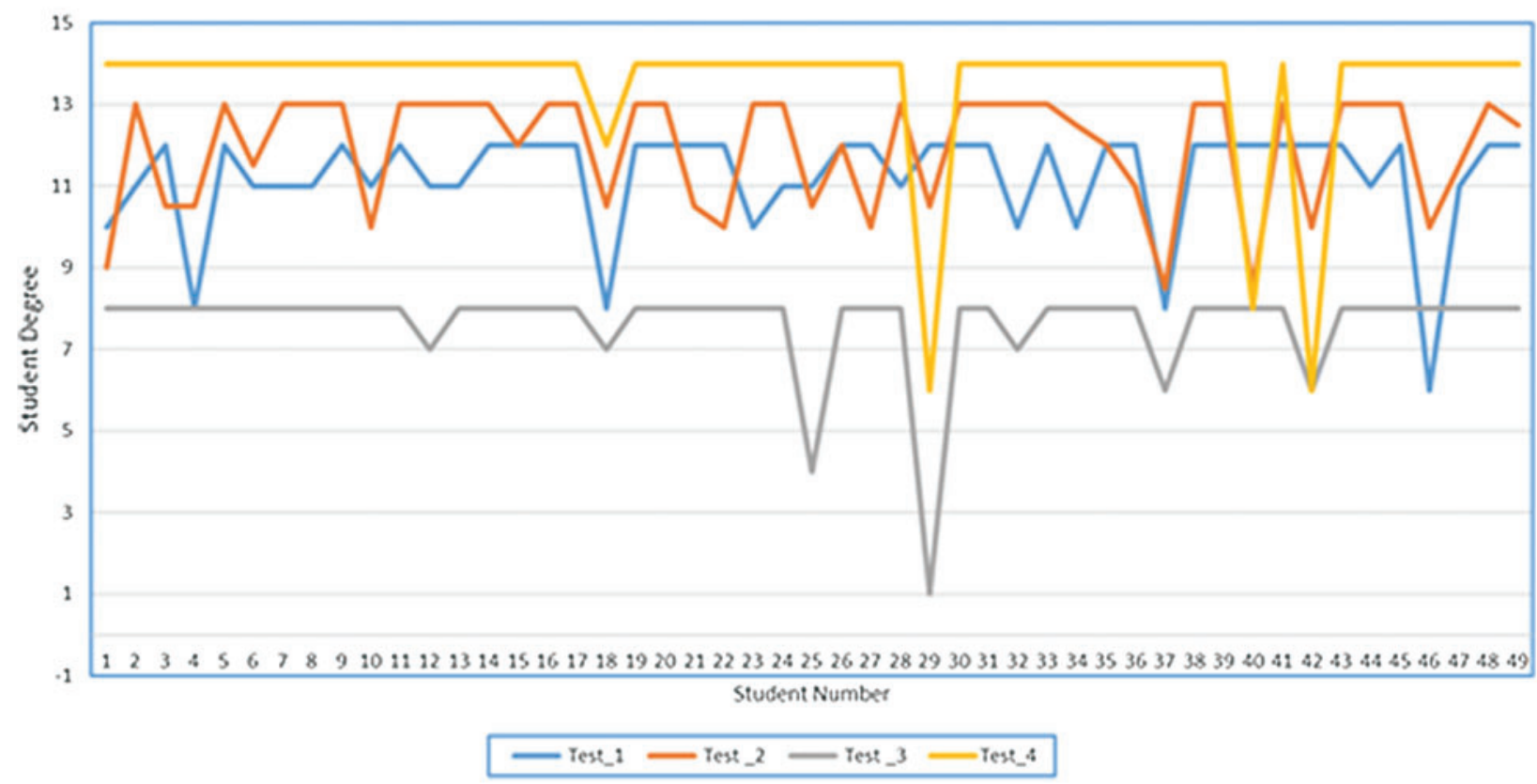

Figure 5: Student grades on the post-test and lecturer quizzes for the VCLE group

Traditional Group: Students Degrees with Lectures Quizzes

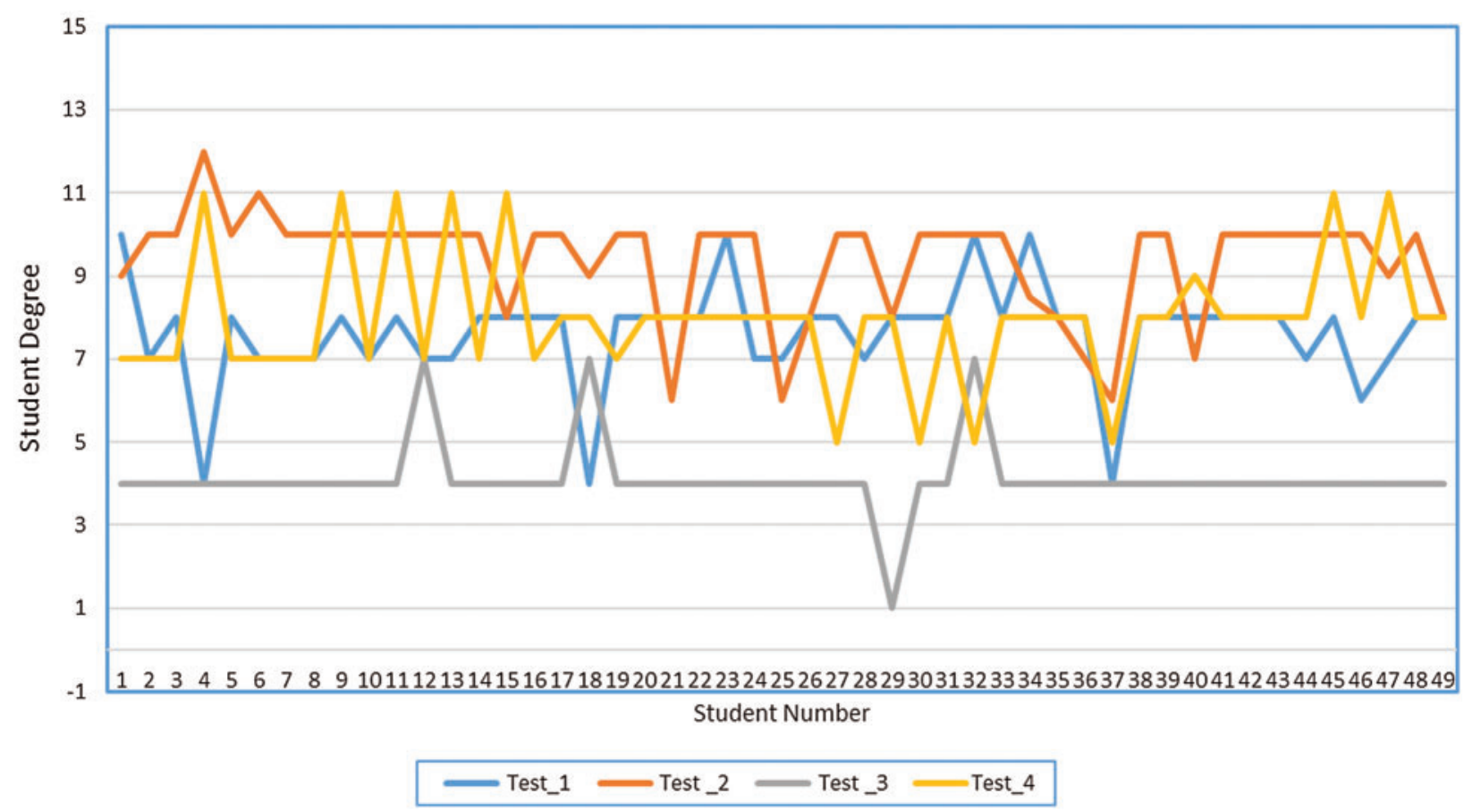

Figure 6: Students' degree in post-test and lecturer quizzes for traditional group 


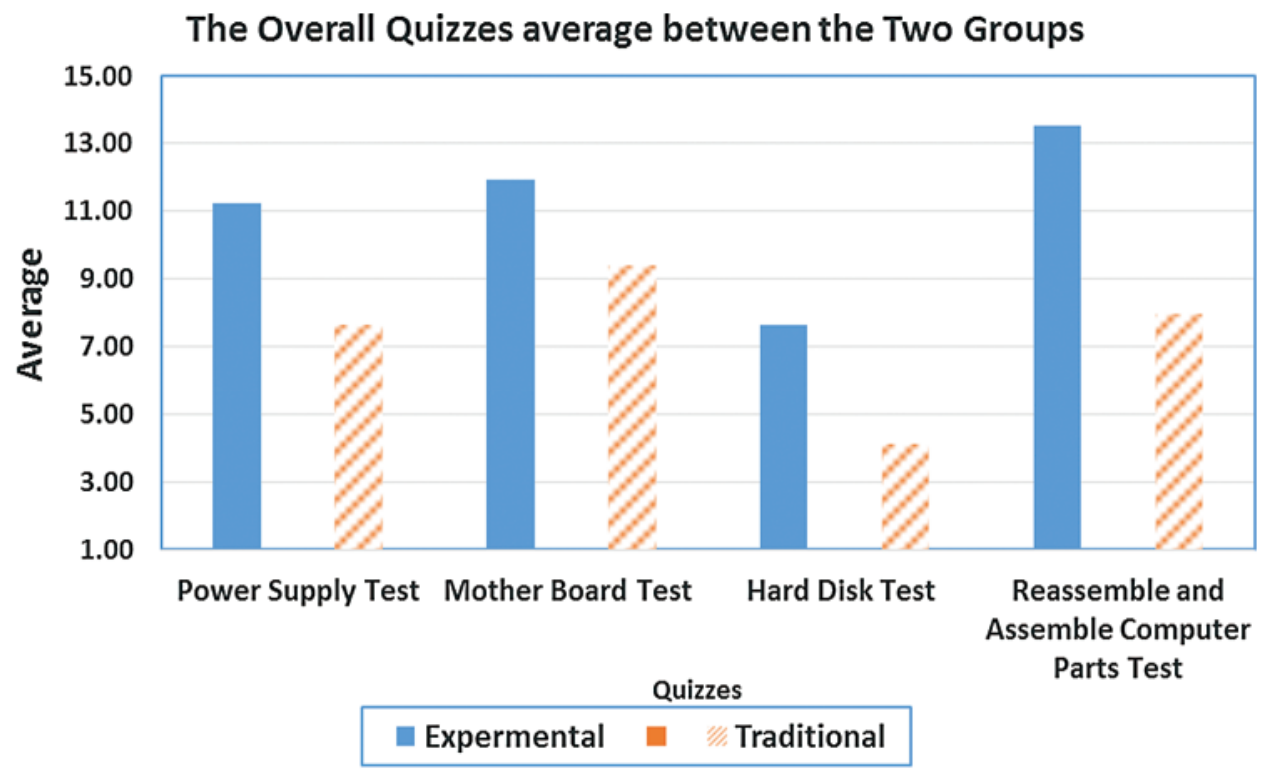

Figure 7: Overall quizzes average between the two groups

Table 7: Descriptive statistics for the rubric criteria according to three assessments

\begin{tabular}{|c|c|c|c|c|c|c|c|c|c|c|}
\hline \multirow[t]{2}{*}{ Criterion } & & \multicolumn{3}{|c|}{ Assessment 1} & \multicolumn{3}{|c|}{ Assessment 2} & \multicolumn{3}{|c|}{ Assessment 3} \\
\hline & & $\mathrm{M}$ & SD & SEM & $\mathrm{M}$ & SD & SEM & $\mathrm{M}$ & $\mathrm{SD}$ & SEM \\
\hline \multirow{2}{*}{$\begin{array}{l}\text { Familiarity } \\
\text { (Identification of } \\
\text { different hardware) }\end{array}$} & $V C L E$ & 9.96 & 0.53 & 0.75 & 9.74 & 0.527 & 0.08 & 9.74 & 0.53 & 0.08 \\
\hline & $T$ & 8.52 & 1.51 & 0.210 & 8.70 & 1.34 & 0.19 & 8.52 & 1.50 & 0.21 \\
\hline \multirow{2}{*}{$\begin{array}{l}\text { Detailing function of } \\
\text { computer part }\end{array}$} & $V C L E$ & 9.58 & 0.76 & 0.11 & 9.58 & 0.758 & 0.11 & 9.58 & 0.76 & 0.11 \\
\hline & $T$ & 6.90 & 0.86 & 0.12 & 7.12 & 1.06 & 0.15 & 6.90 & 0.86 & 0.12 \\
\hline \multirow[t]{2}{*}{ Safety } & $V C L E$ & 9.96 & 0.28 & 0.04 & 9.96 & 0.28 & 0.04 & 9.96 & 0.28 & 0.04 \\
\hline & $T$ & 7.68 & 1.02 & 0.15 & 9.72 & 12.93 & 1.83 & 7.68 & 1.02 & 0.14 \\
\hline \multirow[t]{2}{*}{ Accuracy } & $V C L E$ & 9.96 & 0.20 & 0.28 & 9.96 & 0.198 & 0.028 & 9.96 & 0.20 & 0.023 \\
\hline & $T$ & 8.00 & 0.00 & 0.00 & 8.16 & 0.37 & 0.052 & 8.00 & 0.00 & 0.00 \\
\hline \multirow{2}{*}{$\begin{array}{l}\text { Identify malfunctions } \\
\text { and solve them }\end{array}$} & $V C L E$ & 9.98 & 0.14 & 0.00 & 9.98 & 0.14 & 0.020 & 9.98 & 0.14 & 0.02 \\
\hline & $T$ & 9.00 & 0.00 & 0.00 & 9.22 & 0.42 & 0.059 & 9.00 & 0.00 & 0.00 \\
\hline \multirow{2}{*}{$\begin{array}{l}\text { Organization } \\
\text { (Presenter and oral } \\
\text { presentation) }\end{array}$} & $V C L E$ & 9.98 & 0.14 & 0.02 & 9.98 & 0.14 & 0.020 & 9.74 & 0.20 & 0.080 \\
\hline & $T$ & 8.00 & 0.00 & 0.00 & 8.16 & 0.37 & 0.052 & 7.96 & 0.57 & 0.028 \\
\hline \multirow[t]{2}{*}{ Appearance (Presenter) } & $V C L E$ & 9.98 & 0.14 & 0.020 & 9.98 & 0.14 & 0.020 & 9.98 & 0.14 & 0.02 \\
\hline & $T$ & 7.00 & 0.00 & 0.00 & 7.34 & 0.72 & 0.10 & 7.00 & 0.00 & 0.00 \\
\hline
\end{tabular}


Table 8: ANOVA results for the rubric criteria according to three assessments

\begin{tabular}{|c|c|c|c|c|c|c|c|c|c|c|c|c|c|}
\hline \multirow[t]{2}{*}{ Criterion } & & \multicolumn{4}{|c|}{ Assessment 1} & \multicolumn{4}{|c|}{ Assessment 2} & \multicolumn{4}{|c|}{ Assessment 3} \\
\hline & & SS & MS & $\mathrm{F}$ & Sig. & SS & MS & $\mathrm{F}$ & Sig. & SS & MS & $\mathrm{F}$ & Sig. \\
\hline \multirow{9}{*}{$\begin{array}{l}\text { (a) Familiarity } \\
\text { (Identification } \\
\text { of different } \\
\text { hardware) } \\
\text { (b) Detailing } \\
\text { function of } \\
\text { computer part } \\
\text { (c) Safety }\end{array}$} & Between & 37.21 & 87.210 & \multirow{3}{*}{29.38} & \multirow{3}{*}{0.00} & 27.040 & 27.040 & \multirow{3}{*}{25.949} & \multirow{3}{*}{0.00} & 23.04 & 23.04 & \multirow{3}{*}{15.79} & \multirow{3}{*}{0.00} \\
\hline & & & & & & & & & & & & & \\
\hline & Within & 124.10 & 1.266 & & & 102.120 & 1.042 & & & 142.96 & 1.46 & & \\
\hline & Between & 179.56 & 179.56 & \multirow{4}{*}{272.06} & \multirow{4}{*}{0.00} & 151.29 & 151.29 & \multirow{2}{*}{\multicolumn{2}{|c|}{177.65}} & 166.41 & 166.42 & \multirow{4}{*}{236.42} & \multirow{4}{*}{0.00} \\
\hline & & & & & & & & & & & & & \\
\hline & Within & 64.68 & 0.66 & & & 83.46 & 0.85 & & & 68.98 & 0.70 & & \\
\hline & Between & 129.96 & 129.96 & & & 1.44 & 1.44 & 171.07 & $>0.05$ & 73.38 & 102.01 & & \\
\hline & & & & \multirow[t]{3}{*}{232.41} & \multirow[t]{3}{*}{0.00} & & & & & & & \multirow[t]{2}{*}{136.24} & \multirow[t]{2}{*}{0.00} \\
\hline & Within & 54.80 & 0.56 & & & 8192.00 & 83.59 & & & 0.749 & 0.75 & & \\
\hline \multirow[t]{3}{*}{ (d) Accuracy } & Between & 96.04 & 96.04 & & & 81.00 & 81.00 & & & 57.76 & 57.76 & \multirow{3}{*}{159.90} & \multirow{3}{*}{0.00} \\
\hline & & & & \multirow[t]{3}{*}{4902.04} & \multirow[t]{3}{*}{0.00} & & & 918.75 & 0.00 & & & & \\
\hline & Within & 1.92 & 0.02 & & & 8.640 & 0.088 & & & 35.40 & 0.36 & & \\
\hline \multirow{6}{*}{$\begin{array}{l}\text { (e) Identify } \\
\text { malfunctions } \\
\text { and solve them } \\
\text { (f) Organization } \\
\text { (Presenter and } \\
\text { oral } \\
\text { presentation) }\end{array}$} & Between & 24.01 & 24.01 & & & 14.44 & 14.44 & & & 7.84 & 7.84 & \multirow{3}{*}{30.54} & \multirow[b]{2}{*}{0.00} \\
\hline & & & & \multirow[t]{2}{*}{2401.00} & \multirow[t]{2}{*}{0.00} & & & 148.03 & 0.00 & & & & \\
\hline & Within & 0.98 & 0.01 & & & 9.56 & 0.098 & & & 25.16 & 0.26 & & \\
\hline & Between & 98.01 & 98.01 & \multirow{3}{*}{9801.00} & & 82.81 & 82.81 & & & 79.21 & 79.21 & & \\
\hline & & & & & 0.00 & & & 1053.95 & 0.00 & & & 442.56 & 0.00 \\
\hline & Within & 0.98 & 0.01 & & & 7.700 & 0.079 & & & 17.54 & 0.18 & & \\
\hline (g) Appearance & Between & 222.01 & 222.01 & & & 1.44 & 174.24 & & & 5.76 & 5.76 & & \\
\hline (Presenter) & & & & 22201.00 & 0.00 & & & 651.74 & 0.00 & & & 21.98 & 0.00 \\
\hline & Within & 0.98 & 0.010 & & & 8192.00 & 0.27 & & & 25.68 & 0.26 & & \\
\hline
\end{tabular}

\subsection{Cloud-Based VCLE System Using the Rubric}

Tabs. 7 and 8 show the means and SDs for each rubric criterion using three assessments. Responses from the VCLE group were generally the most positive, and the highest mean score was achieved by the VCLE group for Criterion 5 (9.98), indicating that students in the VCLE group were better at identifying and solving malfunctions than were their peers in the traditional group. Also, the VCLE group did the best oral presentations; the students demonstrated self-efficacy.

Tab. 9 shows the bivariate correlation for student performance between the post-test and rubric assessments, and Fig. 8 illustrates the relation in the VCLE group in Assessment 3, using criteria (a) to (g). The VCLE group had positive relationships in all evaluations, and the traditional group had negative connections in Accuracy, Organization (Presenter and Oral Presentation), and Appearance (Presenter).

Tab. 10 shows the Means and standard deviation results, and rubric assessment for disassembly and reassembly of the system unit, and Tab. 11 presents one-way ANOVA results. The results indicate that responses from the VCLE group were generally the most positive, and the high mean score achieved by the VCLE group for all criteria. Also, this is significant for functionality, senses and timeliness using the VCLE. The overall results indicate that the VCLE group participants interacted with the cloud computing system more frequently than once. Also, VCLE students have the capability of achieving maintenance course goals than the traditional method. 
Table 9: Bivariate correlation for students' grade post-test and rubric assessments

\begin{tabular}{lllllllll}
\hline & Group & $\operatorname{Rup}^{\text {Asses1 }}$ & $\operatorname{Rup}^{\text {Asses2 }}$ & $\operatorname{Rup}^{\text {Asses3 }}$ & $\mathrm{Rup}^{\text {Asses4 }}$ & $\mathrm{Rup}^{\text {Asses5 }}$ & $\mathrm{Rup}^{\text {Asses6 }}$ & $\operatorname{Rup}^{\text {Asses } 7}$ \\
\hline Assess 1 & VCLE group & 0.097 & 0.207 & -0.059 & -0.084 & $0.348^{*}$ & $0.618^{* *}$ & 0.258 \\
& Traditional group & -0.110 & 0.024 & 0.179 & -0.115 & -0.115 & -0.021 & 0.083 \\
Assess 2 & VCLE group & 0.177 & 0.207 & $0.311^{*}$ & 0.191 & $0.628^{* *}$ & $0.623^{* *}$ & $0.368^{* *}$ \\
& Traditional group & 0.049 & 0.024 & 0.179 & 0.181 & 0.237 & -0.021 & 0.083 \\
Assess 3 & VCLE group & $0.772^{* *}$ & $0.435^{* *}$ & 0.256 & $0.464^{* *}$ & $0.697^{* *}$ & $0.777^{* *}$ & $0.466^{* *}$ \\
& Traditional group & 0.144 & 0.042 & 0.206 & 0.223 & $0.296^{*}$ & $0.288^{*}$ & $0.310^{*}$ \\
\hline
\end{tabular}

Notes: ${ }^{* *}$ Correlation is significant at the 0.01 level (2-tailed). ${ }^{*}$ Correlation is significant at the 0.05 level.

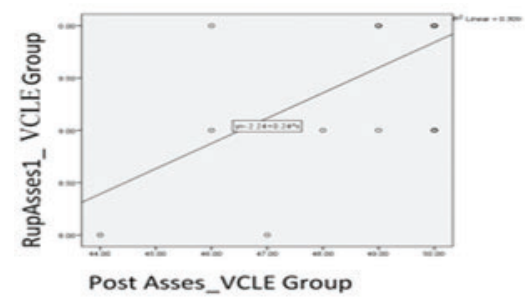

(a)

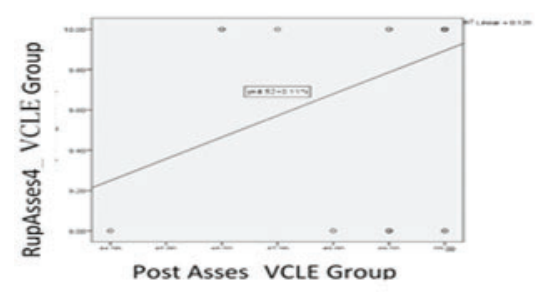

(d)

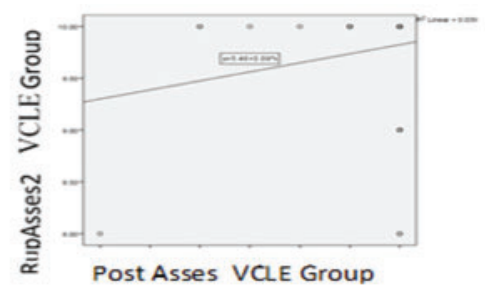

(b)

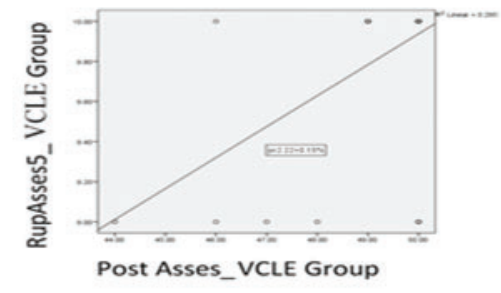

(e)

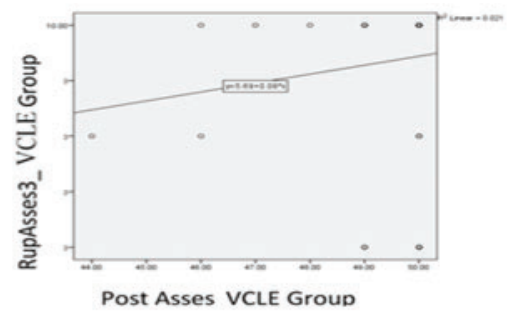

(c)

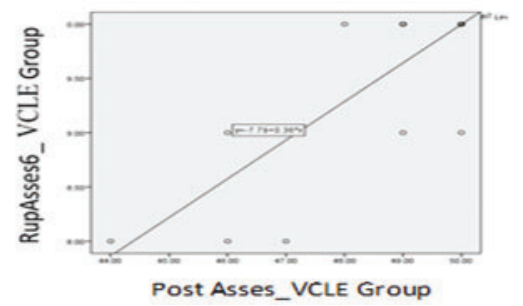

(f)

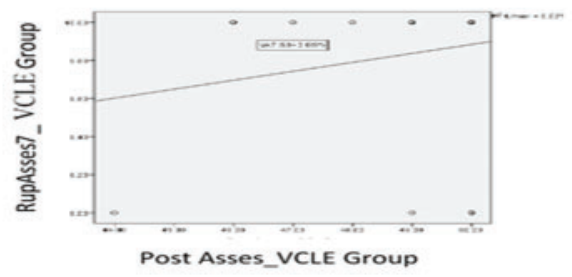

(g)

Figure 8: Correlation between student grades on the post-test and rubric assessments for the VCLE group for assessment 3 
Table 10: Means and SDs for the specific rubric for disassembly and reassembly of the system unit

\begin{tabular}{llll}
\hline Criterion & Group & $\mathrm{M}$ & $\mathrm{SD}$ \\
\hline Accuracy & $V C L E$ & 10.00 & 0.000 \\
& $T$ & 9.96 & 0.283 \\
Familiarity & $V C L E$ & 10.00 & 0.000 \\
& $T$ & 8.96 & 0.283 \\
Functionality & $V C L E$ & 10.00 & 0.000 \\
& $T$ & 8.04 & 0.402 \\
Senses & $V C L E$ & 10.00 & 0.000 \\
& $T$ & 8.7200 & 0.45356 \\
Timeliness & $V C L E$ & 9.88 & 0.43519 \\
& $T$ & 8.74 & 0.44309 \\
\hline
\end{tabular}

Table 11: Descriptive statistics for the specific rubric for disassembly and reassembly of the system unit

\begin{tabular}{llllll}
\hline Criterion group & & SS & MS & F & Sig. \\
\hline Accuracy & Between & 0.040 & 0.04 & 1.00 & 0.320 \\
Familiarity & Within & 3.92 & 0.04 & & \\
& Between & 27.040 & 27.04 & 676.00 & 0.000 \\
Functionality & Within & 3.92 & 0.04 & & \\
& Between & 96.04 & 96.04 & 1188.37 & 0.000 \\
Senses & Within & 7.92 & 0.081 & & \\
& Between & 40.96 & 40.96 & 398.22 & 0.000 \\
Timeliness & Within & 10.08 & 0.103 & & \\
& Between & 32.490 & 32.490 & 168.467 & 0.000 \\
& Within & 18.900 & 0.193 & & \\
\hline
\end{tabular}

\section{Conclusion}

COVID-19 has entered the world scene as a deeply shaking, worldwide pandemic. This paper emphasizes how online learning is beneficial during the pandemic and presents a VCLE system that connects CCL and VR environments to improve student's performance and solve the practical problems that occur in a Computer Maintenance course. CCS and VR were examined to holistically quantify students' performance and activities in the learning environment. The experiment results have shown significant differences between the groups and assessments. Specifically, the VCLE group demonstrated higher performance in comparison with the traditional group. The upper-grade groups were also distinguished through the results. On the contrary, we can conclude that the VCLE approach may contribute to transforming students' views on learning computer maintenance from one of memorizing facts or practicing drills to a more advanced perspective that includes seeking deeper understanding, identifying issues, and problem-solving. Finally, the findings represent a novel contribution to university policymakers for utilizing the proposed system 
to ensure successful usage of e-learning. The proposed system identifies the factors that support the adaption of the e-learning system. Furthermore, research should be performed to discuss the deficiencies of this paper. First, it is necessary to communicate with each student and understand the determinants that impact students' academic achievement (e.g., students' negative or positive attitudes, their attempts) which will help the lecturer to understand the educational scene. Second, we should build an intelligent system that gives automated feedback to enhance awareness of the online learning system that includes student performance and prediction model.

Funding Statement: The authors received no specific funding for this study.

Conflicts of Interest: The authors declare that they have no conflicts of interest to report regarding the present study.

\section{References}

[1] M. A. Almaiah, A. Al-Khasawneh and A. J. Althunibat, "Exploring the critical challenges and factors influencing the E-learning system usage during COVID-19 pandemic," Education Information Technologies, vol. 25, 1, 2020.

[2] P. K. Jena, "Online learning during lockdown period for COVID-19 in India," Editorial Board, vol. 9, no. 5 , pp. $82,2020$.

[3] U. UNESCO, "Distance learning solutions," 2020. [Online]. https:/en.unesco.org/covid19/educationres ponse/solutions.

[4] M. S. Bajwa, "A concern towards data security in cloud computing," International Journal of Computer Applications, vol. 114, no. 11, pp. 17-19, 2015.

[5] R. Kop and F. J. Carroll, "Cloud computing and creativity: Learning on a massive open online course," European Journal of Open, Distance and E-Learning, vol. 14, no. 2, pp. 1-11, 2011.

[6] N. El-Ala, W. Awad and H. J. El-Bakry, "Cloud computing for solving E-learning problems," Editorial Preface, vol. 3, no. 12, pp. 135-137, 2012.

[7] A. Bhattacherjee and S. C. Park, "Why end-users move to the cloud: A migration-theoretic analysis," European Journal of Information Systems, vol. 23, no. 3, pp. 357-372, 2014.

[8] V. J. Ratten, "A US-China comparative study of cloud computing adoption behavior," Journal of Entrepreneurship in Emerging Economies, vol. 6, no. 1, pp. 35-71, 2014.

[9] Q. Alajmi and A. Sadiq, "What should be done to achieve greater use of cloud computing by higher education institutions," in IEEE 7th Annual Information Technology, Electronics and Mobile Communication Conf. (IEMCON), Vancouver, BC, Canada, IEEE, pp. 1-5, 2016.

[10] K. Chine, "Learning math and statistics on the cloud, towards an EC2-based google docs-like portal for teaching/learning collaboratively with $\mathrm{R}$ and Scilab," in 2010 10th IEEE Int. Conf. on Advanced Learning Technologies, Sousse, Tunisia, IEEE, pp. 752-753, 2010.

[11] K. Verma and M. Rizvi, "Impact of cloud on E-learning," in 5th Int. Conf. and Computational Intelligence and Communication Networks, Mathura, India, IEEE, pp. 480-485, 2013.

[12] A. Elgelany and W. G. Alghabban, "Cloud computing: Empirical studies in higher education," International Journal of Advanced Computer Science and Applications, vol. 8, no. 10, pp. 1-12, 2017.

[13] W. Chen-Feng and H. J. Liang-Pang, "Developing the environment of information technology education using cloud computing infrastructure," American Journal of Applied Sciences, vol. 8, no. 9, pp. 864-871, 2011.

[14] M. J. Al-Zoube, "E-Learning on the cloud," International Arab Journal of E-Technology, vol. 1, no. 2, pp. 58-64, 2009.

[15] E. K. Kurelović, S. Rako and J. Tomljanović, "Cloud computing in education and student's needs," in 36th Int. Convention on Information and Communication Technology, Electronics and Microelectronics (MIPRO), Opatija, Croatia, 2013, IEEE, pp. 726-731, 2013. 
[16] T. Ercana, "Differences of web computing and cloud computing," Procedia-Social and Behavioral Sciences, vol. 2, no. 2, pp. 938-942, 2010.

[17] M. Cha, S. Han, J. Lee and B. J. Choi, "A virtual reality based fire training simulator integrated with fire dynamics data," Fire Safety Journal, vol. 50, pp. 12-24, 2012.

[18] D. Passig, D. Tzuriel and G. J. Eshel-Kedmi, "Improving children's cognitive modifiability by dynamic assessment in 3d immersive virtual reality environments," Computers \& Education, vol. 95, pp. 296-308, 2016.

[19] L. Chittaro and R. Ranon, "Web3d technologies in learning, education and training," Computers \& Education, vol. 1, no. 49, pp. 1-2, 2007.

[20] L. F. Johnson and A. H. Levine, "Virtual worlds: Inherently immersive, highly social learning spaces," Theory Into Practice, vol. 47, no. 2, pp. 161-170, 2008.

[21] M. Ott and M. Tavella, "A contribution to the understanding of what makes young students genuinely engaged in computer-based learning tasks," Procedia: Social and Behavioral Sciences, vol. 1, no. 1, pp. 184-188, 2009.

[22] K. W. Lau and P. Y. Lee, "The use of virtual reality for creating unusual environmental stimulation to motivate students to explore creative ideas," Interactive Learning Environments, vol. 23, no. 1, pp. 3-18, 2015.

[23] H. M. Sabi, F. Uzoka, K. Langmia and F. Njeh, "Conceptualizing a model for adoption of cloud computing in education," International Journal of Information Management, vol. 36, no. 2, pp. 183-191, 2016.

[24] Y. M. Reddy and H. J. Andrade, "A review of rubric use in higher education," Assessment \& Evaluation in Higher Education, vol. 35, no. 4, pp. 435-448, 2010.

[25] H. Hussein, "Cloud computing in E-learning," Journal of Information Technology, Imam Al-Kadhum College (IKC), 2020.

[26] M. M. Adrah, G. A. Elmarash and E. E. Eljadi, "The possibility of using cloud computing technology in e-learning at elmergib university," International Conference on Technical Sciences (ICST2019), vol. 6, pp. 4, 2019.

[27] W. W. Liao and R. G. Ho, "Applying observational learning in the cloud education system of art education in an elementary school," in IEEE 11 th Int. Conf. on Advanced Learning Technologies, Athens, Georgia, USA, IEEE, pp. 131-135, 2011.

[28] J. Derboven, D. Geerts and D. De Grooff, "Appropriating virtual learning environments: A study of teacher tactics," Journal of Visual Languages \& Computing, vol. 40, pp. 20-35, 2017.

[29] S. Barney, M. Khurum, K. Petersen, M. Unterkalmsteiner and R. Jabangwe, "Improving students with rubric-based self-assessment and oral feedback," IEEE Transactions on Education, vol. 55, no. 3, pp. 319-325, 2011.

[30] H. M. Huang, U. Rauch and S. Liaw, "Investigating learners' attitudes toward virtual reality learning environments: Based on a constructivist approach," Computers \& Education, vol. 55, no. 3, pp. 11711182, 2010.

[31] A. Bell, R. Mladenovic and M. J. Price, "Students' perceptions of the usefulness of marking guides, grade descriptors and annotated exemplars," Assessment \& Evaluation in Higher Education, vol. 38, no. 7, pp. 769-788, 2013.

[32] E. Panadero and M. J. Romero, "To rubric or not to rubric? the effects of self-assessment on selfregulation, performance and self-efficacy," Assessment in Education: Principles, Policy \& Practice, vol. 21, no. 2, pp. 133-148, 2014.

[33] A. Cockett and C. J. Jackson, "The use of assessment rubrics to enhance feedback in higher education: An integrative literature review," Nurse Education Today, vol. 69, pp. 8-13, 2018.

[34] P. Mell and T. J. Grance, "Draft NIST working definition of cloud computing. National Institute of standards and technology," Information Technology Laboratory, vol. 15, no. 32, 2009.

[35] M. A. Islam, F. B. Kasem, S. Khan, T. Habib and F. Ahmed, "Cloud computing in education: Potentials and challenges for Bangladesh," International Journal of Computer Science, Engineering and Applications, vol. 7, no. 5, pp. 11-21, 2017. 
[36] S. M. Brookhart and F. Chen, "The quality and effectiveness of descriptive rubrics," Educational Review, vol. 67, no. 3, pp. 343-368, 2015.

[37] H. T. Hung, Y. C. Chiu and H. C. Yeh, "Multimodal assessment of and for learning: A theory-driven design rubric," British Journal of Educational Technology, vol. 44, no. 3, pp. 400-409, 2013.

[38] A. L. Kenworthy and G. Hrivnak, "To rubric or not to rubric: That is the question," Journal of Management Education, vol. 38, no. 3, pp. 345-351, 2014.

[39] E. Al Agha and M. Al Ostaz, "The Educational Research: Elements, Methods and Tools," The Islamic University of Gaza, SAGE Publishing, 1996.

[40] K. Ayebi-Arthur, "E-learning, resilience and change in higher education: Helping a university cope after a natural disaster," E-Learning and Digital Media, vol. 14, no. 5, pp. 259-274, 2017. 